\title{
The Impact of Biodiesel Fuel on Ethanol/Diesel Blends
}

\author{
Nawar Al-Esawi ${ }^{1}$, Mansour Al Qubeissi ${ }^{1,2, * \mathbb{C}}$ and Ruslana Kolodnytska ${ }^{3}$ \\ 1 Institute for Future Transport and Cities, Coventry University, Coventry CV1 5FB, UK; \\ esawin@coventry.ac.uk \\ 2 School of Mechanical, Aerospace and Automotive Engineering, Faculty of Engineering, Environment and \\ Computing, Coventry University, Coventry CV1 2JH, UK \\ 3 Faculty of Mechanical Engineering, Zhytomyr State Technological University, Zhytomyr 10002, Ukraine; \\ ruslanakolod2017@gmail.com \\ * Correspondence: mansour.qubeissi@coventry.ac.uk; Tel.: +44-(0)2477-658-060
}

Received: 15 March 2019; Accepted: 7 May 2019; Published: 12 May 2019

\begin{abstract}
The interest in biofuels was stimulated by the fossil fuel depletion and global warming. This work focuses on the impact of biodiesel fuel on ethanol/diesel (ED) fuel blends. The soybean methyl ester was used as a representative composition of typical biodiesel fuels. The heating and evaporation of ethanol-biodiesel-diesel (EBD) blends were investigated using the Discrete-Component (DC) model. The Cetane Number (CN) of the EBD blends was predicted based on the individual hydrocarbon contributions in the mixture. The mixture viscosity was predicted using the Universal Quasi-Chemical Functional group Activity Coefficients and Viscosity (UNIFAC-VISCO) method, and the lower heating value of the mixture was predicted based on the volume fractions and density of species and blends. Results revealed that a mixture of up to $15 \%$ biodiesel, $5 \%$ ethanol, and $80 \%$ diesel fuels had led to small variations in droplet lifetime, $\mathrm{CN}$, viscosity, and heating value of pure diesel, with less than $1.2 \%, 0.2 \%, 2 \%$, and $2.2 \%$ reduction in those values, respectively.
\end{abstract}

Keywords: biodiesel; cetane number; diesel; ethanol; fuel blend; heating and evaporation

\section{Introduction}

The energy demand is sharply increasing along with the increases in worldwide population and global fossil fuel consumption. Currently, more than $99 \%$ of the transport sector is powered by combustion engines, which contribute to around $14 \%$ of greenhouse gas emissions (GGE) [1]. Due to the need for reducing GGE, which contribute to global warming, and the depletion of fossil fuels, governments and industries are aiming to shift from the dependency on fossil fuels to renewable energy sources (e.g., biofuels) [2,3]. The mixture of biofuels (e.g., biodiesel and ethanol) with fossil fuels in standard propulsion systems can reduce GGE and lead to complete combustion [4-6]. According to the UK Department for Transport, the British Government has increased the percentage of bio/fossil fuel blends from $4.75 \%$ (currently) to $9.75 \%$ in 2020 [7]. Therefore, it is important to investigate the feasibility of increasing the bio-/fossil-fuel fractions.

There have been numerous studies on bio-fossil fuel blends for automotive applications, such as ethanol-gasoline, biodiesel-diesel, and ethanol-diesel (ED) blends [8-10]. The ED blend, however, is found to be not practical due to the poor solubility of ethanol in diesel and the negative impact of ethanol on the Cetane Number (CN) [11-15]. Therefore, researchers have started to add some agents to stabilize the mixture and attain the required $\mathrm{CN}[16,17]$. Dimethyl ether $\left(\mathrm{C}_{2} \mathrm{H}_{6} \mathrm{O}\right)$ is a suitable $\mathrm{CN}$ booster when it is mixed with diesel, as it has a $\mathrm{CN}$ of greater than 55 [18]. However, we believe that this molecule cannot be used in diesel engines effectively due to its lower values of molecular weight, boiling point, and density, which makes it evaporate much faster than diesel fuel molecules. Among other different agents, biodiesel is a chemically-convenient additive to mix with ED fuel [19]. 
The most recent studies conducted have focused on the ethanol-biodiesel-diesel (EBD) fuel blend. For instance, Kwanchareon et al. [17] studied the GGE and the CN of this fuel blend. The presence of biodiesel in EBD blend resulted in a significant reduction in the Carbon monoxide (CO) and Hydrocarbon (HC) emissions of internal combustion engines (ICE) compared to the ED blend. In [20], the solubility of EBD blend was investigated at two different temperatures, which showed that the solubility of ethanol increased when increasing the temperature. Beatrice et al. [21] studied the influence of blending $10 \%$ biodiesel, $20 \%$ ethanol, and $70 \%$ diesel fuels on ICE performance. In the latter study, the smoke and Nitrogen Oxides $\left(\mathrm{NO}_{\mathrm{X}}\right)$ emissions were found to be significantly less than those of pure diesel. The impact of EBD blend on emissions was investigated experimentally in [22], where results showed that the EBD blend had lower $\mathrm{NO}_{X}$ emissions compared to those of pure diesel. Similarly, in [23-27], the EBD blend was $\mathrm{CN}$-richer and its combustion produced less $\mathrm{NO}_{\mathrm{X}}$ emissions than diesel combustion. According to [19,28], up to $25 \%$ of biodiesel and $10 \%$ of ethanol could be blended with diesel effectively. In brief, previous studies on EBD blends only focused on the solubility, toxic emissions, heating value and $\mathrm{CN}$ of these blends. The impact of such blends on droplet heating and evaporation, with consideration to full fuel compositions, has not been investigated to the best of our knowledge.

The heating and evaporation of multi-component fuel droplets are essential processes for various combustion applications $[29,30]$. These processes have been widely investigated and different models have been proposed in [31,32], and validated in [33-36]. Some studies have been made to envisage the feasibility of blending biofuels with fossil fuels in terms of heating and evaporation [35,37]. In this paper, the new key findings are the investigation into mixing different fractions of EBD blends with consideration of their droplet lifetimes and surface temperatures, viscosities, and CN. The basic equations of heating and evaporation model and types of fuels, used in the current analysis, are described in Section 2. The results and their discussion are provided in Section 3. The findings are concluded in Section 4.

\section{Model}

Our analysis of the blended fuel droplet heating and evaporation is based on the Discrete-Component (DC) model for a spherically symmetric droplet. The heat and mass transfer equations are solved analytically in this model, using the Effective Thermal Conductivity (ETC) and Effective Diffusivity (ED) models, as will be described later in this section. In the latter models, several physics inside droplets associated with fuel heating and evaporation are considered, for example, temperature and species gradient, and recirculation due to moving droplets [29,32].

The transient heat transfer equation for the temperature $T=T(t, R)$ in the liquid phase in a spherical droplet is [32]:

$$
\frac{\partial T}{\partial t}=\kappa\left(\frac{\partial^{2} T}{\partial R^{2}}+\frac{2}{R} \frac{\partial T}{\partial R}\right)
$$

where $R$ is the distance from the center of the droplet (assumed to be spherical), $T$ is the temperature, $t$ is time in seconds, and $\kappa$ is effective thermal diffusivity accounting for the recirculation inside droplet, defined as:

$$
\kappa=k_{\text {eff }} / c_{l} \rho_{l} .
$$

$c_{l}$ is the liquid specific heat capacity, $\rho_{l}$ is the liquid density, and $k_{\text {eff }}$ is the effective thermal conductivity, defined as:

$$
k_{\text {eff }}=\chi k_{l}
$$

where $k_{l}$ is the liquid thermal conductivity, and $\chi$ is the recirculation coefficient [38]. $\chi$ varies between 1 (when Peclet number $P e_{d(1)}=\operatorname{Re}_{d(1)} \operatorname{Pr}_{1}<10$ ) and 2.72 (for $P e_{d(1)}>500$ ). The analysis based on Equation (3) is described as the Effective Thermal Conductivity (ETC) approach. 
The initial and boundary conditions are introduced as:

$$
\left.\begin{array}{c}
T(t=0)=T_{d 0}(R) \\
h\left(T_{g}-T_{S}\right)=\left.k_{\text {eff }} \frac{\partial T}{\partial R}\right|_{R=R_{d}-0}
\end{array}\right\}
$$

where $T_{s}=T_{s}(t)$ is the surface temperature of droplet, $R_{d}$ is the droplet radius, $h$ is the heat transfer coefficient, and $T_{g}=T_{g}(t)$ is the ambient temperature. To take into account the effect of evaporation, the ambient temperature $\left(T_{g}\right)$ is replaced by the so-called effective temperature $\left(T_{\text {eff }}\right)$ :

$$
T_{\text {eff }}=T_{\mathrm{g}}+\frac{\rho_{l} L \dot{R}_{d e}}{h}
$$

where $L$ is the latent heat of evaporation and $\dot{R}_{d e}$ is the rate of change of droplet radius due to evaporation. The mass fraction diffusion of liquid species $i$ is described as:

$$
\frac{\partial Y_{l i}}{\partial t}=D_{\text {eff }}\left(\frac{\partial^{2} Y_{l i}}{\partial R^{2}}+\frac{2}{R} \frac{\partial Y_{l i}}{\partial R}\right)
$$

where $D_{\text {eff }}$ is the effective diffusivity. The $D_{\text {eff }}$ and the diffusion coefficient in the liquid phase are correlated by the following equation:

$$
D_{\text {eff }}=\chi_{Y} D_{l}
$$

$\chi_{Y}$ is the coefficient of recirculation inside droplet. The analysis based on Equation (7) is known as the Effective Diffusivity (ED) approach. The droplet evaporation is estimated using the following correlation:

$$
\dot{m}_{d}=-2 \pi R_{d} D_{v} \rho_{\text {total }} B_{M} \mathrm{Sh}_{\text {iso }}
$$

where $D_{v}$ is the coefficient of vapor diffusion in the gas phase, $\rho_{\text {total }}=\rho_{g}+\rho_{v}$ is the total mixture density of vapor and gas, $\mathrm{Sh}_{\text {iso }}$ is the Sherwood number of isolated droplets, $B_{M}=\frac{Y_{v s}-Y_{\infty}}{1-Y_{v s}}$ is the Spalding mass transfer number, $Y_{v s}$ is the vapor mass fraction in the vicinity of the droplet, and $Y_{\infty}$ is the far-field vapor mass fraction, with $Y_{v s}=\sum_{i} Y_{v i s}$ and $Y_{v i s}$ being the vapor mass fractions of group and individual species $(i)$, respectively. $Y_{\text {vis }}$ is determined using the vapor molar fractions on the surface of $\operatorname{droplet}\left(X_{v i s}\right)$, as:

$$
X_{v i s}=\gamma_{i} \frac{X_{l i s} p_{v i s}^{*}}{p},
$$

where $p$ is the ambient air pressure, $X_{l i s}$ is the molar fraction in the liquid phase of $i^{\text {th }}$ species at the droplet surface, $\gamma_{i}$ is the Activity Coefficient (AC) of the $i^{\text {th }}$ species, and $p_{v i s}^{*}$ is the saturated pressure of the $i^{\text {th }}$ species in the absence of other species.

Due to the presence of ethanol, which forms a highly non-ideal solution when it mixes with diesel fuel, the Universal Quasi-Chemical Functional group Activity Coefficients (UNIFAC) model is used to predict the AC of 106 components of the EBD blends. In fact, AC is used to correct the vapor pressure of each individual component. The UNIFAC model is presented in greater detail in [39]. However, as this is the first study to deal with the UNIFAC model for the EBD blend to the best of our knowledge, we have included two tables in Appendix A for the UNIFAC groups' parameters and their interaction parameters [40].

The diesel fuel used in this work conforms to standard European Union fuel (EN590). It consists of 98 components divided into nine groups according to their chemical structures. Molar fractions of various components of this fuel and their physical properties are inferred from [41]. Biodiesel is represented by soybean, formed of seven methyl ester components. The molar fractions and physical properties of these components are inferred from [42,43]. Soybean is a type of biodiesel fuel which refers to single alkyl esters of a long-chain fatty acid derived from vegetable oils. The physical properties of 
ethanol (anhydrous) are inferred from [35]. The physical properties for each component are calculated, with appropriate blending rules, to form the average properties of the blend.

\section{Results}

\subsection{Heating and Evaporation}

The impact of different fractions of EBD blends (the EBD blends are referred to as Ex/By/Dz, where $\mathrm{x}, \mathrm{y}$ and $\mathrm{z}$ are the fractions of ethanol, biodiesel and diesel fuels, respectively) on the lifetimes and surface temperatures of droplets is studied using the DC model. Following [36], the droplet with initial temperature $T_{d}=360 \mathrm{~K}$ was assumed to be moving in stationary air at an axial velocity of $U_{d}=10 \mathrm{~m} / \mathrm{s}$. The initial radius of droplet was assumed to be equal to $12.66 \mu \mathrm{m}$. The ambient temperature and pressure were assumed to be constant and equal to $T_{g}=800 \mathrm{~K}$ and $p_{g}=30 \mathrm{bar}$, respectively. The evolutions of droplet radii are shown in Figure 1, and their surface temperatures are presented in Figure 2.

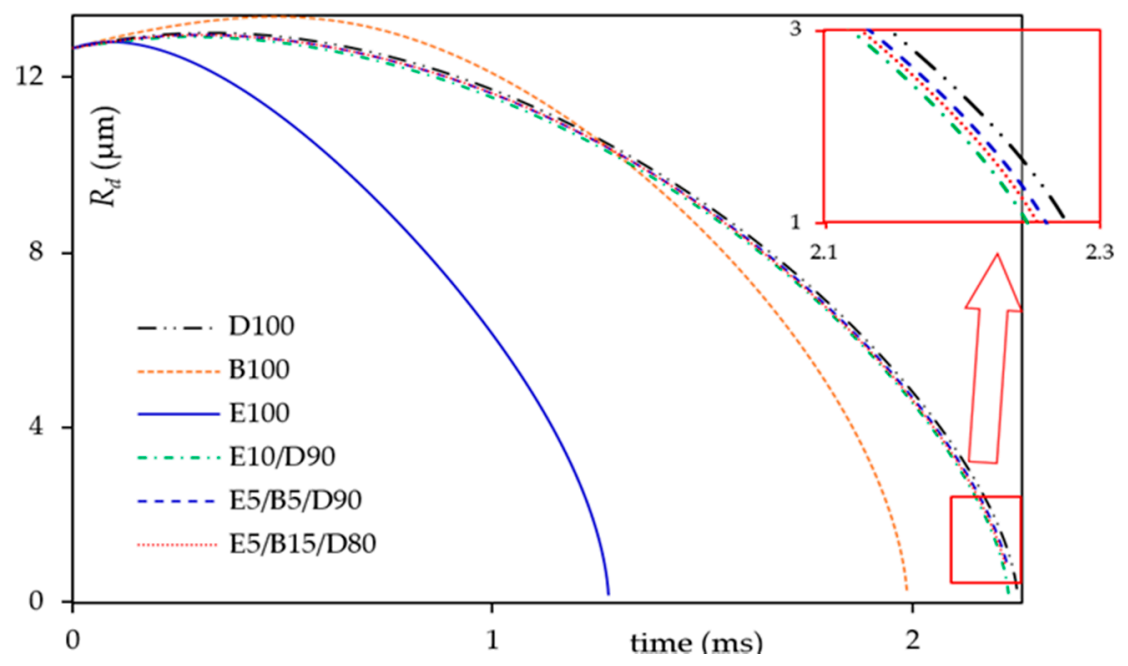

Figure 1. The evolution of droplet radii for pure diesel (indicated as D100), pure biodiesel (indicated as B100), pure ethanol (indicated as E100), and three different ethanol-biodiesel-diesel (EBD) blends.

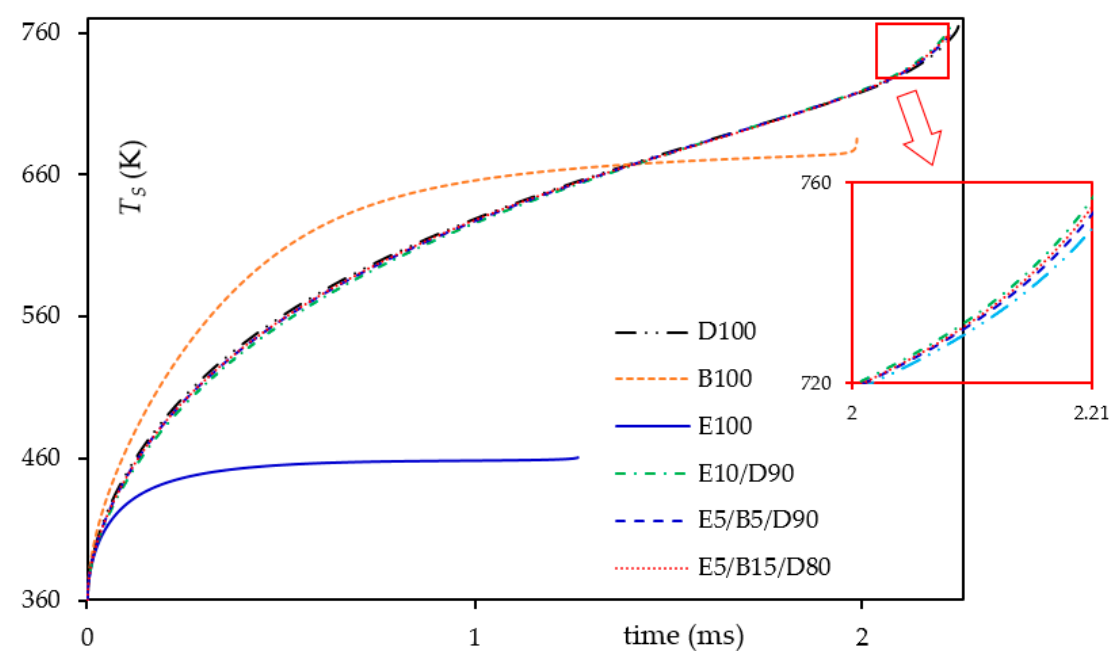

Figure 2. The evolution of droplet surface temperatures for the same fuels and their blends as in Figure 1.

As presented in Figure 1, the droplet lifetime decreased as the fractions of biodiesel, ethanol, or both fuels increased at the expense of diesel fuel. This decrease was $0.7 \%$ when a blend of 
E5/B5/D90 was used, and further decreased by $0.9 \%$ when $10 \%$ of ethanol was mixed with $90 \%$ of diesel. This reduction reached up to $1.2 \%$ when the total fraction of biofuels was $20 \%$ (15\% biodiesel and 5\% ethanol). Predictions showed that pure biodiesel and pure ethanol had $11.7 \%$ and $43.3 \%$, respectively, less droplet lifetime than pure diesel. This shorter droplet lifetime was ascribed to the fact that ethanol and biodiesel had higher vapor pressures than diesel, which made them evaporate faster than pure diesel.

Similarly, droplet surface temperature decreased with increasing biofuels fractions. A reduction of up to $0.5 \%$ was predicted for the E5/B5/D90 blend compared to the pure diesel. This decrease reached up to $1 \%$ for the E5/B15/D80 blend. However, the reduction was significant for pure biodiesel and pure ethanol, which were up to $10.6 \%$ and $39.4 \%$, respectively, compared to pure diesel. This was attributed to the higher heat of capacity of biodiesel and ethanol, as components with higher heat capacity have lower temperature rise.

According to the predicted deviations in droplet surface temperatures and lifetimes between pure diesel and its EBD blends, it can be said that up to 15\% biodiesel, 5\% ethanol, and 80\% diesel can replace the diesel fuel without any modification to the automotive system.

\subsection{Cetane Number and Viscosity}

In order to further illustrate the feasibility of mixing different fractions of biofuels with diesel, some important characteristics were investigated. $\mathrm{CN}$ is one of the most important characteristics of diesel fuel, as it measures the combustion quality of diesel fuel [44]. The presence of ethanol in diesel results in a reduction in its $\mathrm{CN}$ and viscosity, which is another important property that influences the quality of atomization and combustion [26,45]. Therefore, biodiesel fuel was used to compensate the decrease in the aforesaid two properties [16]. The impact of biodiesel fuel on the $\mathrm{CN}$ of ethanol-diesel blends was predicted using the formula suggested in [46]. The $\mathrm{CN}$ of pure diesel fuel $\left(\mathrm{CN}_{\mathrm{D}}\right)$ was predicted using the formula suggested in [47], as follows:

$$
\mathrm{CN}_{\mathrm{D}}=\frac{\sum_{i} v_{i} \beta_{i} \mathrm{CN}_{\mathrm{i}}}{\sum_{i} v_{i} \beta_{i}}
$$

For each species group, $v_{i}$ is the total volume fraction, $\beta_{i}$ is the blending parameter, and $\mathrm{CN}_{\mathrm{i}}$ is the cetane number of that group. The $\mathrm{CN}$ number for each component is inferred from [47-50]. It should be emphasised that the n-alkanes and iso-alkanes groups were merged together in [41] to form one group due to their similar physical properties. For the predictions of the $\mathrm{CN}$, however, these two groups were considered separately due to the impact of varying component structures (straight chain or branched) on the $\mathrm{CN}$. The predictions of the $\mathrm{CN}_{\mathrm{D}}$, using Equation (10), is presented in Table 1. Note that the last three groups of diesel fuel presented in [41], have been ignored due to their small volume fractions ( $1.8 \%$ tricycloalkanes, $0.8 \%$ diaromatics, and $0.5 \%$ phenanthrenes).

Table 1. The volume fractions and parameters of each group of diesel fuel and their predicted Cetane Number (CN).

\begin{tabular}{lcc}
\hline \multicolumn{1}{c}{ Groups } & $\boldsymbol{v}_{\boldsymbol{i}}$ & $\boldsymbol{\beta}_{\boldsymbol{i}}$ \\
\hline n-alkanes & 15.94 & 0.5212 \\
iso-alkanes & 31.32 & 7.3717 \\
cycloalkanes & 15.99 & 0.0727 \\
bicycloalkanes & 7.53 & 0.0727 \\
aromatics & 12.84 & 3.1967 \\
tetralines & 10.39 & 3.1967 \\
naphthalenes & 5.97 & 0.0727 \\
\multicolumn{2}{c}{$\mathrm{CN}_{\mathrm{D}}=54.5$} \\
\hline
\end{tabular}


The CN number of each component present in biodiesel fuel was predicted using the formula suggested in [51], which was based on the carbon number of the component and the number of double-bonds existing in each component. Then, the following formula, which was suggested in [52], was used for the predictions of the $\mathrm{CN}$ of biodiesel fuel $\left(\mathrm{CN}_{\mathrm{B}}\right)$. Note that $\mathrm{CN}_{\mathrm{B}}$ depends on molecular structure. Methyl lineolate $\left(\mathrm{C}_{19} \mathrm{H}_{34} \mathrm{O}_{2}\right)$, for instance, has very low $\mathrm{CN}(23)$. Based on this, not all types of biodiesel can compensate the reduction of $\mathrm{CN}$ caused by ethanol. However, SME fuel had small fractions of methyl lineolate which made it an appropriate fuel to boost the $\mathrm{CN}_{\mathrm{B}}$ of the blend.

$$
\mathrm{CN}_{\mathrm{B}}=1.068 \sum\left(\mathrm{CN}_{i} w_{i}\right)-6.747,
$$

where $\mathrm{CN}_{i}$ and $w_{i}$ are the $\mathrm{CN}$ number and mass fraction, respectively, of component $i$ in the biodiesel fuel.

The $\mathrm{CN}$ of the EBD blend was predicted using the formula suggested in [46] and compared with the volume fraction mixing rule for the predictions of $\mathrm{CN}$ of EBD blends. The latter formula suggested in [46] illustrates that each 1 vol. \% of ethanol causes a decrease in $\mathrm{CN}$ by 0.6 units which will be well compensated by 0.55 units for each 1 vol. \% of biodiesel. The impact of different fractions of ethanol and biodiesel on the CN of the EBD blend is shown in Table 2.

Table 2. Predicted CN of biodiesel, diesel, ethanol, and their blends.

\begin{tabular}{lcc}
\hline EBD vol.\% & CN [53] & CN [46] \\
\hline D100 & 54.5 & 54.5 \\
B100 & 56.4 & 56.4 \\
E100 & 8.0 & 8.0 \\
E10/D90 & 49.8 & 48.6 \\
E5/B5/D90 & 52.3 & 54.4 \\
E5/B15/D90 & 52.5 & 55.0 \\
\hline
\end{tabular}

Zöldy [46] suggested a correlation to predict the viscosity of EBD blends based on several experimental measurements [46]. Such an approach may not predict the viscosity of our analyzed blends. A more rigorous approach will need to be considered to predict the viscosity of a blend of species with different structures. Therefore, we used the UNIFAC-VISCO method which is described as [40]:

$$
\ln \eta_{m}=\sum_{i} x_{i} \ln \left(\eta_{i} V_{i}\right)-\ln V_{m}+\frac{\Delta^{*} g^{E C}}{R T}+\frac{\Delta^{*} g^{R C}}{R T},
$$

where $\eta_{m}$ is the mixture viscosity and $\eta_{i}$ is the viscosity of $i^{t h}$ component, respectively. $V_{m}$ and $V_{i}$ are the volumes of the mixture and $i^{\text {th }}$ component, respectively, $\frac{\Delta^{*} g^{E C}}{R T}=\sum_{i} x_{i} \ln \frac{\Phi_{i}}{X_{i}}+\frac{z}{2} \sum_{i} x_{i} q_{i} \ln \frac{\theta_{i}}{\Phi_{i}}$, and $\frac{\Delta^{*} g^{E R}}{R T}=-\sum_{i} x_{i} \ln \gamma_{i}^{* R}$. All the terms and parameters appearing in Equation (12) and their related terms are the same as those for the UNIFAC model (see [39] for more details). The application of Equation (12) for the predictions of the EBD viscosity is summarized in Table 3.

Table 3. Predicted viscosity (at $T=40^{\circ} \mathrm{C}$ ) of biodiesel, diesel, ethanol, and their blends.

\begin{tabular}{lc}
\hline \multicolumn{1}{c}{ EBD vol.\% } & $\eta_{\boldsymbol{m}}$ (cP) \\
\hline D100 & 3.51 \\
B100 & 3.59 \\
E100 & 0.81 \\
E10/D90 & 3.27 \\
E5/B5/D90 & 3.46 \\
E5/B15/D80 & 3.44 \\
\hline
\end{tabular}

As can be seen from Tables 2 and 3, the addition of $15 \%$ biodiesel and $5 \%$ ethanol resulted in up to $0.2 \%$ and $2 \%$ reduction in the $\mathrm{CN}$ and viscosity, respectively, compared to pure diesel, which can be 
sacrificed in diesel engines. In fact, the presence of biodiesel compensated the reduction in the CN and viscosity caused by ethanol, as the E10/D90 blend had approximately $10.8 \%$ and $7 \%$ less $\mathrm{CN}$ and viscosity, respectively, compared to pure diesel.

\subsection{Heating Value}

The impact of biodiesel and ethanol additions on the heating value (HV) of diesel was predicted for different EBD blends using the following formula [54]:

$$
\mathrm{HV}_{\text {blend }}=\left(v_{B} \mathrm{HV}_{D} \rho_{D}+v_{B} \mathrm{HV}_{B} \rho_{B}+v_{E} \mathrm{HV}_{E} \rho_{E}\right) / \rho_{\text {blend }},
$$

where $\mathrm{HV}_{D}, \mathrm{HV}_{B}$, and $\mathrm{HV}_{E}$ refer to the heating values (in $\mathrm{MJ} / \mathrm{kg}$ ) of diesel, biodiesel, and ethanol respectively; and $v_{D}, v_{B}$, and $v_{E}$ refer to the volume fractions of diesel, biodiesel, and ethanol respectively. $\rho_{D}, \rho_{B}, \rho_{E}$, and $\rho_{\text {blend }}$ refer to the densities of diesel, biodiesel, ethanol, and their blend, respectively. The solution to Equation (13) was compared to the experimental data of [17], and presented in Figure 3 (see Table A2 for the blends in $\mathrm{x}$-axis of Figure 3).

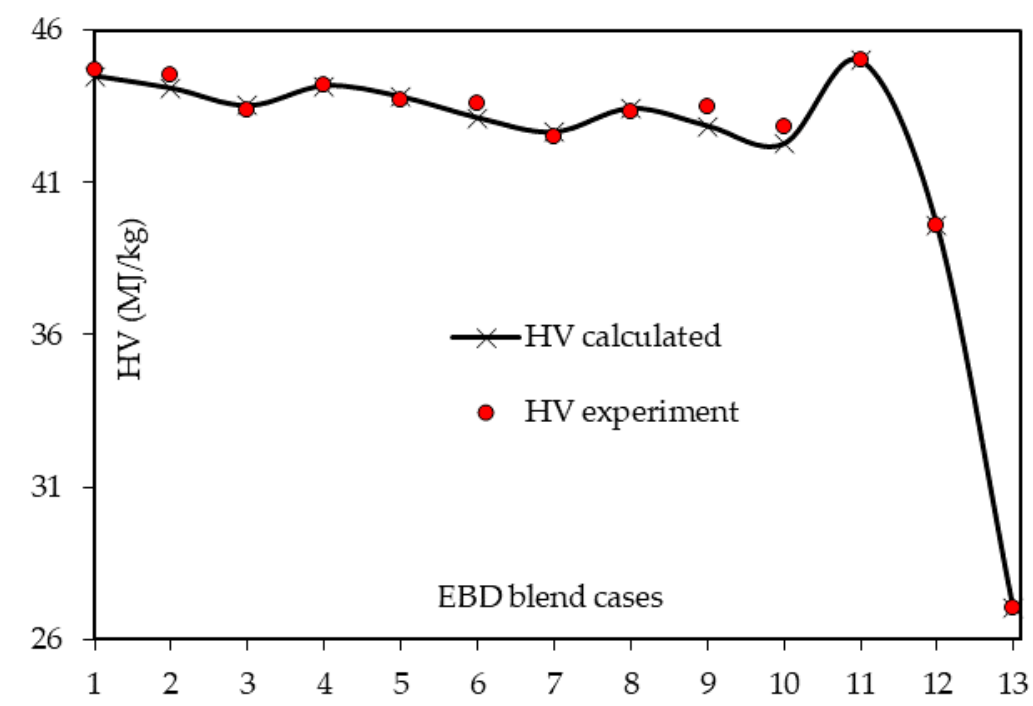

Figure 3. The predicted heating value, experimentally measured in [17], for ethanol, biodiesel, diesel, and their blends. The $\mathrm{x}$-axis blend cases are illustrated in Table 4.

Table 4. The cases of EBD blends used in Figure 3.

\begin{tabular}{cccc}
\hline Sample & $\mathbf{\% D}$ & $\mathbf{\% B}$ & $\mathbf{\% E}$ \\
\hline 1 & 90 & 10 & 0 \\
2 & 90 & 5 & 5 \\
3 & 90 & 0 & 10 \\
4 & 85 & 15 & 0 \\
5 & 85 & 10 & 5 \\
6 & 85 & 5 & 10 \\
7 & 85 & 0 & 15 \\
8 & 80 & 15 & 5 \\
9 & 80 & 10 & 10 \\
10 & 80 & 5 & 15 \\
11 & 100 & 0 & 0 \\
12 & 0 & 100 & 0 \\
13 & 0 & 0 & 100 \\
\hline
\end{tabular}

As shown in Figure 3, the predicted HVs were in agreement with the experimental data. The HV of ethanol (case 13) was very low due to its small structure. The addition of biodiesel had compensated 
the reduction in HV caused by ethanol. For instance, E10/D90 (case 3) had 3\% less HV compared to pure diesel, while E5/B5/D90 had only 0.5 less HV compared to pure diesel. Predictions showed that our target blend (E5/B15/B80) has 2.2\% less HV compared to pure diesel, which can be tolerated in diesel engines.

\section{Conclusions}

The combining of biofuels with fossil fuels has received significant attention during the last two decades due to the depletion of fossil fuels and the need for reducing the GGE which contribute to global warming. In this study, we investigated the feasibility of mixing different fuel fractions of biodiesel and ethanol with diesel in terms of heating and evaporation characteristics, Cetane Number $(\mathrm{CN})$, viscosity, and heating value. The aforesaid characteristics and properties are essential for the design of engines to ensure their good performance.

Predictions revealed that the presence of biodiesel at the expense of ethanol (e.g., $5 \%$ biodiesel and $5 \%$ ethanol, instead of only $10 \%$ of ethanol) compensated the reduction in droplet lifetime, surface temperature, $\mathrm{CN}$, viscosity, and even the heating value. It was found that a blend of $15 \%$ biodiesel, $5 \%$ ethanol, and $80 \%$ diesel fuels led to less than $1.2 \%, 0.2 \%, 2 \%$, and $2.2 \%$ reduction in droplet lifetime, $\mathrm{CN}$, viscosity and heating value, respectively, compared to those of pure diesel fuel.

It can be concluded that the presence of biofuels with up to $20 \%$ in diesel fuel can be used in engines designed for pure diesel with minimal, or no, modification requirement.

Author Contributions: Conceptualization, M.A.Q.; methodology, N.A.; software, M.A.Q. and N.A; validation, N.A. and R.K.; formal analysis, N.A. and R.K.; investigation, N.A. and R.K.; resources, N.A., R.K. and M.A.Q.; data curation, M.A.Q.; writing—original draft preparation, N.A.; writing—review and editing, M.A.Q.; visualization, N.A.; supervision, M.A.Q.; project administration, M.A.Q.; funding acquisition, M.A.Q.

Funding: This study is based upon work funded by the European Commission and the British Council (project Reference: 2018-1-UK01-KA107-047386), and Coventry University (Grant No. ECR019).

Acknowledgments: The authors are grateful to S.S. Sazhin of the University of Brighton for useful discussion, and Coventry University (Grant No. ECR019) for the financial support of this project.

Conflicts of Interest: The authors declare no conflict of interest.

\section{Appendix A}

The $R_{k}$ and $Q_{k}$ for different groups in biodiesel, diesel, and ethanol components are shown in Table A1, which are inferred from [40].

Table A1. Van der Waals volumes $\left(R_{k}\right)$ and surface areas $\left(Q_{k}\right)$ for various molecules and atoms.

\begin{tabular}{ccccc}
\hline Name & Group & Group Number & $\boldsymbol{R}_{\boldsymbol{k}}$ & $\boldsymbol{Q}_{\boldsymbol{k}}$ \\
\hline \multirow{3}{*}{ alkanes } & $\mathrm{CH}_{3}$ & 1 & 0.9011 & 0.848 \\
& $\mathrm{CH}_{2}$ & 1 & 0.6744 & 0.540 \\
& $\mathrm{CH}$ & 1 & 0.4469 & 0.228 \\
\hline olefins & $\mathrm{CH}_{2}=\mathrm{CH}$ & 2 & 1.3454 & 1.176 \\
\hline benzenes & $\mathrm{ACH}$ & 3 & 0.5313 & 0.400 \\
\hline \multirow{2}{*}{ alkylbenzenes } & $\mathrm{ACCH}_{3}$ & 4 & 1.2663 & 0.968 \\
& $\mathrm{ACCH}$ & 4 & 1.0396 & 0.660 \\
& $\mathrm{ACCH}$ & 4 & 0.8121 & 0.348 \\
\hline ethanol & $\mathrm{OH}$ & 5 & 1.0000 & 1.200 \\
\hline methyl esters & $\mathrm{CH}_{2} \mathrm{COO}$ & 11 & 1.6764 & 1.188 \\
\hline
\end{tabular}

In Table A1, there are six groups in ethanol, biodiesel, and diesel fuels, and each group interacts with the other five groups. In contrast to our previous work [39], this table includes the van der Waals 
volumes and surface areas of biodiesel fuels (methyl-esters). The $a_{m n}$ between these groups, including those for biodiesel fuel (group 11), are shown in Table A2 [40].

Table A2. The $m$-group and n-group interaction parameters $\left(a_{m n}\right)$ in $\mathrm{K}$, used in the UNIFAC and UNIFAC-VISCO models.

\begin{tabular}{ccccccc}
\hline Group Number & $\boldsymbol{n = 1}$ & $\mathbf{2}$ & $\mathbf{3}$ & $\mathbf{4}$ & $\mathbf{5}$ & $\mathbf{1 1}$ \\
\hline$m=1$ & 0.0 & 86.02 & 61.13 & 76.50 & 986.5 & 232.11 \\
2 & -35.36 & 0.0 & 38.81 & 74.15 & 524.1 & 37.85 \\
3 & -11.12 & 3.446 & 0.0 & 167.0 & 636.1 & 5.994 \\
4 & -69.70 & -113.6 & -146.8 & 0.0 & 803.2 & 5688 \\
5 & 156.4 & 457.0 & 89.6 & 25.82 & 0.0 & 101.1 \\
11 & 114.8 & 132.1 & 85.84 & -170.0 & 245.4 & 0.0 \\
\hline
\end{tabular}

\section{References}

1. Kalghatgi, G. Is it really the end of internal combustion engines and petroleum in transport? Appl. Energy 2018, 225, 965-974. [CrossRef]

2. Kalghatgi, G.; Levinsky, H.; Colket, M. Future transportation fuels. Prog. Energy Combust. Sci. 2018, 69, 103-105. [CrossRef]

3. Ali, O.; Mamat, R.; Najafi, G.; Yusaf, T.; Safieddin Ardebili, S. Optimization of biodiesel-diesel blended fuel properties and engine performance with ether additive using statistical analysis and response surface methods. Energies 2015, 8, 14136-14150. [CrossRef]

4. Abdul Rahim, N.; Mohd Jaafar, M.; Sapee, S.; Elraheem, H. Effect on particulate and gas emissions by combusting biodiesel blend fuels made from different plant oil feedstocks in a liquid fuel burner. Energies 2016, 9, 659. [CrossRef]

5. Qasim, M.; Ansari, T.M.; Hussain, M. Combustion, performance, and emission evaluation of a diesel engine with biodiesel like fuel blends derived from a mixture of pakistani waste canola and waste transformer oils. Energies 2017, 10, 1023. [CrossRef]

6. Jaliliantabar, F.; Ghobadian, B.; Najafi, G.; Yusaf, T. Artificial neural network modeling and sensitivity analysis of performance and emissions in a compression ignition engine using biodiesel fuel. Energies 2018, 11, 2410. [CrossRef]

7. Department for Transport, UK New Regulations to Double the Use of Sustainable Renewable Fuels by 2020. Available online: https://www.gov.uk/government/news/new-regulations-to-double-the-use-of-sustainablerenewable-fuels-by-2020 (accessed on 22 February 2019).

8. Imdadul, H.K.; Masjuki, H.H.; Kalam, M.A.; Zulkifli, N.W.M.; Alabdulkarem, A.; Rashed, M.M.; Teoh, Y.H.; How, H.G. Higher alcohol-biodiesel-diesel blends: An approach for improving the performance, emission, and combustion of a light-duty diesel engine. Energy Convers. Manag. 2016, 111, 174-185. [CrossRef]

9. Li, L.; Wang, J.; Wang, Z.; Xiao, J. Combustion and emission characteristics of diesel engine fueled with diesel/biodiesel/pentanol fuel blends. Fuel 2015, 156, 211-218. [CrossRef]

10. Novaes, T.L.C.C.; Henríquez, J.R.; Ochoa, A.A.V. Numerical simulation of the performance of a diesel cycle operating with diesel-biodiesel mixtures. Energy Convers. Manag. 2019, 180, 990-1000. [CrossRef]

11. Satgé de Caro, P. Interest of combining an additive with diesel-ethanol blends for use in diesel engines. Fuel 2001, 80, 565-574. [CrossRef]

12. Li, D.; Zhen, H.; Li, X.; Zhang, W.; Yang, J. Physico-chemical properties of ethanol-diesel blend fuel and its effect on performance and emissions of diesel engines. Renew. Energy 2005, 30, 967-976. [CrossRef]

13. Torres-Jimenez, E.; Jerman, M.S.; Gregorc, A.; Lisec, I.; Dorado, M.P.; Kegl, B. Physical and chemical properties of ethanol-diesel fuel blends. Fuel 2011, 90, 795-802. [CrossRef]

14. Tutak, W.; Lukács, K.; Szwaja, S.; Bereczky, Á. Alcohol-diesel fuel combustion in the compression ignition engine. Fuel 2015, 154, 196-206. [CrossRef]

15. He, B.-Q.; Shuai, S.-J.; Wang, J.-X.; He, H. The effect of ethanol blended diesel fuels on emissions from a diesel engine. Atmos. Environ. 2003, 37, 4965-4971. [CrossRef] 
16. Pidol, L.; Lecointe, B.; Starck, L.; Jeuland, N. Ethanol-biodiesel-Diesel fuel blends: Performances and emissions in conventional Diesel and advanced Low Temperature Combustions. Fuel 2012, 93, 329-338. [CrossRef]

17. Kwanchareon, P.; Luengnaruemitchai, A.; Jai-In, S. Solubility of a diesel-biodiesel-ethanol blend, its fuel properties, and its emission characteristics from diesel engine. Fuel 2007, 86, 1053-1061. [CrossRef]

18. Kim, H.J.; Park, S.H. Optimization study on exhaust emissions and fuel consumption in a dimethyl ether (DME) fueled diesel engine. Fuel 2016, 182, 541-549. [CrossRef]

19. Shahir, S.A.; Masjuki, H.H.; Kalam, M.A.; Imran, A.; Fattah, I.M.R.; Sanjid, A. Feasibility of diesel-biodiesel-ethanol/bioethanol blend as existing CI engine fuel: An assessment of properties, material compatibility, safety and combustion. Renew. Sustain. Energy Rev. 2014, 32, 379-395. [CrossRef]

20. Silveira, M.B.; do Carmo, F.R.; Santiago-Aguiar, R.S.; de Sant'Ana, H.B. Ab-diesel: Liquid-liquid equilibrium and volumetric transport properties. Fuel 2014, 119, 292-300. [CrossRef]

21. Beatrice, C.; Napolitano, P.; Guido, C. Injection parameter optimization by DoE of a light-duty diesel engine fed by Bio-ethanol/RME/diesel blend. Appl. Energy 2014, 113, 373-384. [CrossRef]

22. Fang, Q.; Fang, J.; Zhuang, J.; Huang, Z. Effects of ethanol-diesel-biodiesel blends on combustion and emissions in premixed low temperature combustion. Appl. Therm. Eng. 2013, 54, 541-548. [CrossRef]

23. Aydın, F.; Öğüt, H. Effects of using ethanol-biodiesel-diesel fuel in single cylinder diesel engine to engine performance and emissions. Renew. Energy 2017, 103, 688-694. [CrossRef]

24. Noorollahi, Y.; Azadbakht, M.; Ghobadian, B. The effect of different diesterol (diesel-biodiesel-ethanol) blends on small air-cooled diesel engine performance and its exhaust gases. Energy 2018, 142, 196-200. [CrossRef]

25. Tse, H.; Leung, C.W.; Cheung, C.S. Investigation on the combustion characteristics and particulate emissions from a diesel engine fueled with diesel-biodiesel-ethanol blends. Energy 2015, 83, 343-350. [CrossRef]

26. Labeckas, G.; Slavinskas, S.; Mažeika, M. The effect of ethanol-diesel-biodiesel blends on combustion, performance and emissions of a direct injection diesel engine. Energy Convers. Manag. 2014, 79, 698-720. [CrossRef]

27. Shahir, S.A.; Masjuki, H.H.; Kalam, M.A.; Imran, A.; Ashraful, A.M. Performance and emission assessment of diesel-biodiesel-ethanol/bioethanol blend as a fuel in diesel engines: A review. Renew. Sustain. Energy Rev. 2015, 48, 62-78. [CrossRef]

28. Mofijur, M.; Rasul, M.G.; Hyde, J.; Azad, A.K.; Mamat, R.; Bhuiya, M.M.K. Role of biofuel and their binary (diesel-biodiesel) and ternary (ethanol-biodiesel-diesel) blends on internal combustion engines emission reduction. Renew. Sustain. Energy Rev. 2016, 53, 265-278. [CrossRef]

29. Sazhin, S.S. Droplets and Sprays; Springer: London, UK, 2014; ISBN 978-1-4471-6385-5.

30. Al Qubeissi, M. Predictions of droplet heating and evaporation: An application to biodiesel, diesel, gasoline and blended fuels. Appl. Therm. Eng. 2018, 136, 260-267. [CrossRef]

31. Sazhin, S.S. Modelling of fuel droplet heating and evaporation: Recent results and unsolved problems. Fuel 2017, 196, 69-101. [CrossRef]

32. Sazhin, S.S. Advanced models of fuel droplet heating and evaporation. Prog. Energy Combust. Sci. 2006, 32, 162-214. [CrossRef]

33. Sazhin, S.S.; Elwardany, A.E.; Krutitskii, P.A.; Deprédurand, V.; Castanet, G.; Lemoine, F.; Sazhina, E.M.; Heikal, M.R. Multi-component droplet heating and evaporation: Numerical simulation versus experimental data. Int. J. Therm. Sci. 2011, 50, 1164-1180. [CrossRef]

34. Elwardany, A.E.; Sazhin, S.S.; Im, H.G. A new formulation of physical surrogates of FACE A gasoline fuel based on heating and evaporation characteristics. Fuel 2016, 176, 56-62. [CrossRef]

35. Al Qubeissi, M.; Al-Esawi, N.; Sazhin, S.S.; Ghaleeh, M. Ethanol/gasoline droplet heating and evaporation: Effects of fuel blends and ambient conditions. Energy Fuels 2018, 32, 6498-6506. [CrossRef]

36. Al-Esawi, N.; Al Qubeissi, M.; Whitaker, R.; Sazhin, S.S. Blended E85-Diesel fuel droplet heating and evaporation. Energy Fuels 2019, 33, 2477-2488. [CrossRef]

37. Al Qubeissi, M.; Sazhin, S.S.; Elwardany, A.E. Modelling of blended Diesel and biodiesel fuel droplet heating and evaporation. Fuel 2017, 187, 349-355. [CrossRef]

38. Abramzon, B.; Sirignano, W.A. Droplet vaporization model for spray combustion calculations. Int. J. Heat Mass Transf. 1989, 32, 1605-1618. [CrossRef] 
39. Al-Esawi, N.; Al Qubeissi, M.; Sazhin, S.S.; Whitaker, R. The impacts of the activity coefficient on heating and evaporation of ethanol/gasoline fuel blends. Int. Commun. Heat Mass Transf. 2018, 98, 177-182. [CrossRef]

40. Poling, B.E.; Prausnitz, J.M.; O'Connell, J.P. The Properties of Gases and Liquids; McGraw-Hill: New York, NY, USA, 2001; ISBN 0-07-011682-2.

41. Sazhin, S.S.; Al Qubeissi, M.; Nasiri, R.; Gun'ko, V.M.; Elwardany, A.E.; Lemoine, F.; Grisch, F.; Heikal, M.R. A multi-dimensional quasi-discrete model for the analysis of Diesel fuel droplet heating and evaporation. Fuel 2014, 129, 238-266. [CrossRef]

42. Sazhin, S.S.; Al Qubeissi, M.; Kolodnytska, R.; Elwardany, A.E.; Nasiri, R.; Heikal, M.R. Modelling of biodiesel fuel droplet heating and evaporation. Fuel 2014, 115, 559-572. [CrossRef]

43. Al Qubeissi, M.; Sazhin, S.S.; Crua, C.; Turner, J.; Heikal, M.R. Modelling of biodiesel fuel droplet heating and evaporation: Effects of fuel composition. Fuel 2015, 154, 308-318. [CrossRef]

44. Pitz, W.J.; Mueller, C.J. Recent progress in the development of diesel surrogate fuels. Prog. Energy Combust. Sci. 2011, 37, 330-350. [CrossRef]

45. Alptekin, E.; Canakci, M. Characterization of the key fuel properties of methyl ester-diesel fuel blends. Fuel 2009, 88, 75-80. [CrossRef]

46. Zöldy, M. Ethanol-biodiesel-diesel blends as a diesel extender option on compression ignition engines. Transport 2011, 26, 303-309. [CrossRef]

47. Ghosh, P.; Jaffe, S.B. Detailed composition-based model for predicting the cetane number of diesel fuels. Ind. Eng. Chem. Res. 2006, 45, 346-351. [CrossRef]

48. Santana, R.; Do, P.; Santikunaporn, M.; Alvarez, W.; Taylor, J.; Sughrue, E.; Resasco, D. Evaluation of different reaction strategies for the improvement of cetane number in diesel fuels. Fuel 2006, 85, 643-656. [CrossRef]

49. Qian, Y.; Yu, L.; Li, Z.; Zhang, Y.; Xu, L.; Zhou, Q.; Han, D.; Lu, X. A new methodology for diesel surrogate fuel formulation: Bridging fuel fundamental properties and real engine combustion characteristics. Energy 2018, 148, 424-447. [CrossRef]

50. Creton, B.; Dartiguelongue, C.; de Bruin, T.; Toulhoat, H. Prediction of the Cetane Number of Diesel Compounds Using the Quantitative Structure Property Relationship. Energy Fuels 2010, 24, 5396-5403. [CrossRef]

51. Lapuerta, M.; Rodríguez-Fernández, J.; de Mora, E.F. Correlation for the estimation of the cetane number of biodiesel fuels and implications on the iodine number. Energy Policy 2009, 37, 4337-4344. [CrossRef]

52. Tong, D.; Hu, C.; Jiang, K.; Li, Y. Cetane number prediction of biodiesel from the composition of the fatty acid methyl esters. J. Am. Oil Chem. Soc. 2011, 88, 415-423. [CrossRef]

53. Shinde, S.; Yadav, S.D. Theoretical properties prediction of diesel-biodiesel-DEE blend as a fuel for C.I. engine with required modifications for optimum performance. Int. J. Curr. Eng. Technol. 2016, 6, 1562-1567.

54. Grabar, I.G.; Kolodnytska, R.V.; Semenov, V.G. Biofuel Based on Oil for Diesel Engines; ZDTU: Zhytomyr, Ukraine, 2011. (In Ukrainian)

(C) 2019 by the authors. Licensee MDPI, Basel, Switzerland. This article is an open access article distributed under the terms and conditions of the Creative Commons Attribution (CC BY) license (http://creativecommons.org/licenses/by/4.0/). 